\title{
KOMUNIKASI DALAM IMPLEMENTASI KEBIJAKAN PENDIDIKAN WAJIB BELAJAR 9 TAHUN DI KECAMATAN NGADILUWIH
}

\author{
Ahmad Khoirul Syani, Shohibul Mufid, dan Mufarrihul Hazin \\ Pendidikan Agama Islam \\ STAIN KEDIRI
}

\begin{abstract}
The Government recognizes the need to improve the quality of education as a tool to improve the quality of human resources. One of them through government policy requires basic education in order to achieve competitiveness of resources. This study aims to find out how this policy is implemented in an area in the aspect of communication and socialization. The method used is through qualitative descriptive approach. The data collection technique is done by interview, observation and documentation, data analysis used by data condensation, data display, and conclusion, data validity is done by checking credibility, dependency, and confirmability. The results of this study indicate that 100\% of children in Ngadiluwih who graduated from primary school went to the next level, and the drop out rate in junior high school only reached $0.6 \%$.
\end{abstract}

Keywords: education policy, Compulsory Learning, communication.

\begin{abstract}
Abstrak
Pemerintah menyadari dengan benar akan kebutuhan peningkatan kualitas pendidikan sebagai alat meningkatkan kualitas sumber daya manusia. Salah satunya melalui kebijakan pemerintah mewajibkan pendidikan dasar 9 tahun, agar tercapai sumber daya yang memiliki daya saing. Penelitian ini bertujuan untuk mengetahui bagaimana kebijakan ini diimplementasikan pada sebuah daerah dalam aspek komunikasi dan sosialisasinya. Metode yang digunakan adalah melalui pendekatan kualitatif deskriptif. Adapun teknik pengumpulan data dilakukan dengan wawancara, observasi dan dokumentasi, analisis data yang digunakan dengan kondensasi data, display data, dan penarikan kesimpulan, keabsahan data dilakukan dengan mengecek kredibilitas, dependibilitas, dan konfirmabilitas. Hasil penelitian ini menunjukkan bahwa $100 \%$ anak di Ngadiluwih yang lulus SD melanjutkan ke jenjang selanjutnya,
\end{abstract}


Ahmad Khoirul Syani, Shohibul Mufid, dan Mufarrihul Hazin : Komunikasi dalam Implementasi Kebijakan Pendidikan Wajib Belajar 9 Tahun Di Kecamatan Ngadiluwih

dan angka putus sekolah pada sekolah menengah pertama hanya mencapai $0,6 \%$.

Kata Kunci: kebijakan pendidikan, wajib belajar, komunikasi.

\section{LATAR BELAKANG}

Pendidikan sangat penting guna membangun peradaban bangsa, hal ini disadari betul oleh pemerintah betapa perlunya peningkatan pendidikan yang ada di Indonesia saat ini. Lewat pendidikan diharapkan mampu meningkatkan kualitas SDM (Sumber daya manusia) yang akan berdampak kepada peradaban bangsa yang maju. Selama ini pemerintah bersama elemen masyarakat, terus berupaya mewujudkan pendidikan melalui berbagai usaha pembangunan pendidikan yang lebih berkualitas, antara lain melalui pengembangan dan perbaikan kurikulum dan sistem evaluasi, perbaikan sarana pendidikan, pengembangan dan pengadaan materi ajar, serta pelatihan bagi guru dan tenaga kependidikkan lainnya.

Pemerintah menyadari dengan benar akan kebutuhan peningkatan kualitas pendidikan sebagai alat meningkatkan kualitas sumber daya manusia. Selain itu, pendidikan merupakan hak bagi setiap warga negara seperti tercantum dalam UUD 1945 Pasal 31. Kemudian, pada tahun 1994 pemerintah melalui Instruksi Presiden Nomor 1 Tahun 1994 tentang Pedoman Pelaksanaan Wajib Belajar Pendidikan Dasar. Kebijakan ini cukup berhasil meningkatkan partisipasi masyarakat dalam mengenyam pendidikan. Dengan demikian diharapkan masyarakat berpartisipasi penuh untuk mensukseskan kebijakan dari pemerintah, sekaligus ikut serta dalam upaya memajukan bangsa lewat pendidikan.

Pada era saat ini, sudah banyak terealisasi dan terlaksana dari kebijakan pendidkkan wajib belajar 9 tahun, jarang sekali anak-anak sekarang yang tidak 
sampai lulus SMP, meskipun ada tetapi sedikit. Mungkin dikarenakan tuntutan zaman dan juga persyaratan kebanyakan lowongan pekerjaan yang mewajibkan berijazah minimal sekolah menengah pertama. Disitu secara tidak langsung juga mendorong masyarakat untuk mau atau tidak mau menyekolahkan anaknya sampai ke jenjang sekolah menengah.

Masalah yang dihadapi saat ini berbeda dengan masa dimana kebijakan ini baru diterapkan, jika yang dulu masalahnya karena minat masyarakat yang rendah, tapi sekarang yang terjadi adalah masyarakat mulai berbondongbondong menyekolahkan anak-anaknya sampai ke sekolah menengah, bahkan sampai ke perguruan tinggi. Hal ini bisa terjadi karena tuntutan keadaan, dimana secara otomatis anak yang tidak menganyam pendidikan sampai sekolah menengah, akan kesulitan mendapat lapangan pekerjaan di kemudian hari.

Selain karena faktor di atas, ada beberapa faktor yang mendukung terlaksananya kebijakan pendidikan wajib belajar Sembilan tahun yang telah disinggung di atas. Salah satunya yaitu adanya komunikasi dalam implementasi kebijakan pendidikan wajib belajar sembilan tahun tersebut. Apabila tidak ada komunikasi dan penyampaian serta sosialisasi yang baik, maka suatu kebijakan tidak dapat terlaksana dengan baik pula. Dari uraian di atas, maka peneliti ingin memaparkan bagaimana komunikasi dan sosialisasi tentang kebijakan pendidikan wajib belajar 9 tahun tersebut disosialisasikan serta diimplementasikan di sebuah daerah..

\section{TEORI KEBIJAKAN PENDIDIKAN}

Landasan pokok keberadaan sistem pendidikan nasional adalah UUD 45 Bab XIII, Pasal 31, ayat (1) Yang menyatakan bahwa: Tiap-tiap warga negara berhak mendapatkan pengajaran. Hal ini mengandung implikasi bahwa sistem 
Ahmad Khoirul Syani, Shohibul Mufid, dan Mufarrihul Hazin : Komunikasi dalam Implementasi Kebijakan Pendidikan Wajib Belajar 9 Tahun Di Kecamatan Ngadiluwih

pendidikan nasional harus mampu memberi kesempatan belajar yang seluasluasnya kepada setiap warga negara.Dengan demikian, dalam penerimaan seseorang sebagai peserta didik, tidak dibenarkan adanya perlakuan yang berbeda yang didasarkan atas jenis kelarruin, agama, ras, suku, Tatar belakang sosial dan tingkat kemampuan ekonomi.

Dalam rangka memperluas kesempatan belajar pendidikan dasar, maka pada tanggal 2 Mel 1994 pemerintah mencanangkan program pendidikan wajib belajar 9 tahun.lebih lanjut dikemukakan bahwa tahap penting dalam pembangunan pendidikan adalah meningkatkan pendidikan wajib belajar 6 tahun menjadi 9 tahun. Pendidikan wajib belajar 9 tahun menganut konsepsi pendidikan semesta (universal basic education), yaitu suatu wawasan untuk membuka kesempatan pendidikan dasar.Jadi sasaran utamanya adalah menumbuhkan aspirasi pendidikan orang tua dan peserta didik yang telah cukup umur untuk mengikuti pendidikan, dengan maksud untuk meningkatkan produktivitas angkatan kerja secara makro. Maksud utamanya adalah agar anakanak memiliki kesempatan untuk terus belajar sampai dengan usia 15 tahun, dan sebagai landasan untuk belajar lebih lanjut baik di jenjang pendidikan lebih tinggi maupun di dunia kerja.

Wajib Belajar 9 Tahun merupakan salah satu program mewajibkan setiap warga negara untuk bersekolah selama 9 (sembilan) tahun pada jenjang pendidikan dasar, yaitu dari tingkat kelas 1 Sekolah Dasar (SD) atau Madrasah Ibtidaiyah (MI) hingga kelas 9 Sekolah Menengah Pertama (SMP) atau Madrasah Tsanawiyah (MTs).Ini ditujukan agar semua masyarakat Indonesia berhak mengenyam pendidikan yang layak dan membantu mengentaskan buta aksara.

Mengenai usia wajib belajar Pasal 6 ayat 1 UU No 20 Tahun 2003 menyebutkan bahwa: "Setiap warga Negara yang berusia tujuh sampai lima 
belas tahun wajib mengikuti pendidikan dasar. Lebih lanjut Pasal 34 UndangUndang Nomor 20 Tahun 2003 tentang Sistem Pendidikan Nasional menetapkan bahwa Pemerintah dan pemerintah daerah menjamin terselenggaranya program wajib belajar minimal pada jenjang pendidikan dasar tanpa memungut biaya. Penyelenggaraan program wajib belajar pendidikan dasar merupakan bagian dari kebijakan pendidikan di Indonesia dalam mencapai pendidikan untuk semua.

Program wajib belajar 9 tahun ini merujuk pada taksonomi yang dibuat untuk mencapai tujuan pendidikan. Tujuan pendidikan di Indonesia menggunakan konsep Taksonomi Bloom. Dalam hal ini, tujuan pendidikan dibagi domain, yaitu:

1. Cognitive Domain (Ranah Kognitif), yang berisi perilaku-perilaku yang menekankan aspek intelektual, seperti pengetahuan, pengertian, dan keterampilan berpikir.

2. Affective Domain (Ranah Afektif) berisi perilaku-perilaku yang menekankan aspek perasaan dan emosi, seperti minat, sikap, apresiasi, dan cara penyesuaian diri.

3. Psychomotor Domain (Ranah Psikomotor) berisi perilaku-perilaku yang menekankan aspek keterampilan motorik seperti tulisan tangan, mengetik, berenang, dan mengoperasikan mesin.

Beberapa istilah lain yang juga menggambarkan hal yang sama dengan ketiga domain tersebut di antaranya seperti yang diungkapkan oleh Ki Hajar Dewantara, yaitu: cipta, rasa, dan karsa, yang dikenal dengan istilah ngerti (mengetahui), ngrasa (memahami) dan nglakoni (melakukan). Dengan penerapan konsep ini diharapkan setiap warga negara dapat mengembangkan dirinya lebih lanjut yang akhirnya mampu memilih dan mendapatkan pekerjaan yang sesuai dengan potensi yang dimiliki, setiap warga negara mampu berperan 
Ahmad Khoirul Syani, Shohibul Mufid, dan Mufarrihul Hazin : Komunikasi dalam Implementasi Kebijakan Pendidikan Wajib Belajar 9 Tahun Di Kecamatan Ngadiluwih

serta dalani kehidupan bermasyarakat berbangsa dan bernegara, dan, memberikan jalan kepada siswa untuk melanjutkan pendidikan ke tingkat yang lebih tinggi.

Dalam hal ini menurut Edward (1980), terdapat empat aspek dalam pengimplementasian suatu kebijakan yakni, dari segi komunikasi, sumber daya, disposisi, dan struktur birokrasi. Namun pada penelitian ini yang lebih ditekankan oleh penulis adalah dari aspek komunikasi, dikarenakan sesuai dengan objek yang sedang diteliti.

\section{METODE PENELITIAN}

1. Pendekatan Dan Jenis Penelitian

Penelitian ini menggunakan pendekatan kualitatif deskriptif. Dengan mendeskripsikan data-data yang diperoleh dari observasi, wawancara dan dokumentasi yang telah dilakukan. Hasil data-data yang telah di peroleh dari narasumber, dideskripsikan dan diuraikan dengan dukungan teori-teori yang ada.

2. Lokasi Penelitian

Penelitian ini dilakukan di UPTD Ngadiluwih yang beralamatkan di Jalan Raya Ngadiluwih No. 785 Desa Purwokerto Kecamatan Ngadiluwih Provinsi Jawa Timur. Penelitian ini dilakukan 2 kali observasi yaitu pada tanggal 3 November dan 21 November.

3. Pengumpulan Data

Teknik pengumpulan data yang digunakan adalah melalui observasi, wawancara, dan dokumentasi. Informan dalam penelitian ini berjumlah 2 orang, yang terdiri dari: kepala UPTD Ngadiluwih, dan 1 orang staff pegawai di UPTD Ngadiluwih tersebut. 


\section{Analisis Data}

Teknik analisis data yang digunakan adalah model analisis data menggunakan teknik analisis model interaktif Miles dan Huberman, yaitu dengan kondensasi data, penyajian data (display data), dan penarikan kesimpulan. Pertama, kondensasi data berarti merangkum, memilih hal-hal yang pokok, memfokuskan pada hal-hal penting dan memilah-milah data sesuai dengan kategori pertanyaan, memilih data yang dianggap penting untuk diambil intinya. Kedua, setelah data dikondensasi peneliti menyajikan (display) data yaitu dapat berupa uraian singkat, foto dan sejenisnya. Langkah ketiga yaitu penarikan kesimpulan dari data yang telah dikumpulkan dengan memahami secara mendalam dan mengambil inti dari hasil penelitian (Sugiyono, 2017: 247).

5. Keabsahan Data

Uji keabsahan data yang digunakan yaitu: uji credibility (melalui triangulasi sumber: yaitu pernyataan kepala sekolah dan dua guru agama dan teknik: wawancara, observasi dan dokumentasi), uji transferability (melalui penyusunan hasil penelitian secara rinci, jelas, sistematis, dan dapat dipercaya supaya orang lain dapat memahami hasil penelitian sehingga ada kemungkinan untuk menerapkan hasil penelitian), uji dependability (melalui audit keseluruhan proses penelitian), dan uji confirmability (melalui publikasi hasil penelitian).

\section{HASIL DAN PEMBAHASAN}

Hasil penelitian yang dipaparkan merupakan hasil analisis dan validasi dari data-data serta informasi yang telah diperoleh dari narasumber yang menjadi objek penelitian. Hasil yang dibahas di dapat melalui observasi, 
Ahmad Khoirul Syani, Shohibul Mufid, dan Mufarrihul Hazin : Komunikasi dalam Implementasi Kebijakan Pendidikan Wajib Belajar 9 Tahun Di Kecamatan Ngadiluwih

wawancara dan dokumentasi yang dilaksanakan langsung satu hari di UPTD Ngadiluwih kecamatan ngadiluwih kabupaten Kediri.

\section{Kebijakan Pendidikan Wajib Belajar 9 Tahun}

Wajib belajar adalah program pendidikan minimal yang harus diikuti oleh warga negara Indonesia atas tanggung jawab pemerintah dan pemerintah daerah. Pendidikan dasar adalah jenjang pendidikan yang melandasi jenjang pendidikan menengah, berbentuk Sekolah Dasar (SD)dan Madrasah Ibtidaiyah (MI) atau bentuk lain yang sederajat serta sekolah menengah pertama (SMP) dan madrasah Tsanawiyah (MTs), atau bentuk lain yang sederajat(PP No. 47 tahun 2008).Hasil penelitian menunjukkan bahwasanya kebijakan pendidikan wajib belajar 9 tahun sudah berjalan dengan baik di kecamatan Ngadiluwih.

Upaya yang dilakukan pemerintah untuk mencerdaskan kehidupan bangsa dan meningkatkan kualitas pendidikan yang ada di Indonesia yang bertujuan agar terciptanya sumber daya manusia yang berkualitas dan memiliki daya saing dengan Negara manapun. Dalam hal ini pemerintah mengeluarkan peraturan pemerintah nomor 47 tahun 2004 yang mewajibkan seluruh warga Negara Indonesia untuk melaksanakan pendidik dasar wajib belajar 9 tahun. Hal ini sejalan dengan realita yang ditemukan penulis di Kecamatan Ngadiluwih dengan respon dan umpan balik dari masyarakat setempat yang sangat baik, guna terselenggaranya kebijakan tersebut agar dapat menciptakan sumber daya yang mumpuni.

\section{Komunikasi dalam Implementasi Kebijakan Pendidikan Wajib Belajar 9 Tahun di Ngadiluwih}

Dalam implementasinya, Keberhasilan implementasi kebijakan akan ditentukan oleh banyak variabel atau faktor, dan masing-masing variabel tersebut saling berhubungan satu sama lain. untuk memperkaya 
pemahaman kita tentang berbagai variabel yang terlibat didalam implementasi, maka dari itu ada pembatasan dalam penelitian ini maka peneliti memilih pendekatan yang dikemukakan oleh Edwards III. Dalam pandangan Edwards III, implementasi kebijakan dipengaruhi oleh empat variabel, yakni: (1) komunikasi, (2) sumberdaya, (3) disposisi, dan (4) struktur birokrasi. Keempat variabel tersebut juga saling berhubungan satu sama lain.

Dalam pembahasan ini penulis hanya akan membahas tentang komunikasi dalam implementasinya saja. Komunikasi menjadi pengaruh nomor 1 dalam implementasi kebijakan karena, awal dari sebuah dijalankannya/di implementasikannya sebuah kebijakan karena ada komunikasi yang di dalamnya terdapat sosialisasi dan lain sebagainya. Tanpa komunikasi yang baik dan merata sebuah kebijakan tidak akan berjalan dengan baik dan merata pula. Hasil penelitian menunjukkan bahwa dalam pengimplementasian kebijakan wajib belajar 9 tahun di Ngadiluwih, sudah berjalan dengan baik dan mencapai angka hampir 100\%. Maka hal itu yang akan menjadi sasaran peneliti bagaimana keberhasilan tersebut bisa dicapai dan akan di bahas dibawah ini.

a. Sosialisasi

Pada tahap sosialisasi, UPTD Ngadiluwih menggunakan cara mensosialisasikan secara langsung kepada peserta didik dan orang tua peserta didik melalui pertemuan-pertemuan yang dilakukan sekolah saat pembagian rapor maupun pertemuan yang lain dan melibatkan petugas UPTD, selain itu, menurut Kepala UPTD Ngadiluwih menjelaskan bahwa tingkat kesadaran masyarakat setempat tentang pentingnya pendidikan juga sangat tinggi, hal ini membuat sosialisasi yang dilakukan menjadi sangat efektif dan efisien. 
Ahmad Khoirul Syani, Shohibul Mufid, dan Mufarrihul Hazin : Komunikasi dalam Implementasi Kebijakan Pendidikan Wajib Belajar 9 Tahun Di Kecamatan Ngadiluwih

b. Kejelasan

Hasil penelitian menunjukkan bahwa kebijakan pendidikan wajib belajar 9 tahun tidak mengalami kesimpangsiuran informasi, hal ini didukung dengan realita yang ada di masyarakat setempat dengan terselenggaranya dengan baik dari komunikasi dalam implementasi kebijakan wajib belajar 9 tahun di kecamatan Ngadiluwih ini.

c. Kontinyunitas dan konsistensi

Pihak UPTD setempat menuturkan bahwasanya untuk mencapai efektifitas dan efisiensi dari sebuah kebijakan tersebut tidak bisa dilakukan dengan sosialisasi sekali saja, namun juga harus kontinyu atau keberlanjutan sosialisasi yang dilakukan, dan juga tidak membuat kesimpangsiuran di masyarakat tentang kebijakan wajib belajar 9 tahun ini.

Hal diatas semua yang telah dipaparkan sejalan dengan sebuah teori bahwa Implementasi akan berjalan efektif apabila ukuran-ukuran dan tujuan-tujuan kebijakan dipahami oleh individu-individu yang bertanggungjawab dalam pencapaian tujuan kebijakan. Kejelasan ukuran dan tujuan kebijakan dengan demikian perlu dikomunikasikan secara tepat dengan para pelaksana. Konsistensi atau keseragaman dari ukuran dasar dan tujuan perlu dikomunikasikan sehingga implementor mengetahui secara tepat ukuran maupun tujuan kebijakan itu.

Komunikasi dalam organisasi merupakan suatu proses yang amat kompleks dan rumit. Seseorang bisa menahannya hanya untuk kepentingan tertentu, atau menyebarluaskannya. Di samping itu sumber informasi yang berbeda juga akan melahirkan interpretasi yang berbeda pula. Agar implementasi berjalan efektif, siapa yang bertanggung jawab melaksanakan sebuah keputusan harus mengetahui apakah mereka dapat melakukannya. 
Sesungguhnya implementasi kebijakan harus diterima oleh semua personel dan harus mengerti secara jelas dan akurat mengenai maksud dan tujuan kebijakan. Jika para aktor pembuat kebijakan telah melihat ketidakjelasan spesifikasi kebijakan sebenarnya mereka tidak mengerti apa sesungguhnya yang akan diarahkan. Para implementor kebijakan bingung dengan apa yang akan mereka lakukan sehingga jika dipaksakan tidak akan mendapatkan hasil yang optimal. Tidak cukupnya komunikasi kepada para implementor secara serius mempengaruhi implementasi kebijakan.

Ada tiga indikator yang dapat digunakan dalam mengukur keberhasilan aspek komunikasi ini, yaitu:

a. Transmisi, yaitu penyaluran komunikasi yang baik akan dapat menghasilkan suatu hasil implementasi yang baik pula. Seringkali yang terjadi dalam proses transmisi ini yaitu adanya salah pengertian, hal ini terjadi karena komunikasi implementasi tersebut telah melalui beberapa tingkatan birokrasi, sehingga hal yang diharapkan terdistorsi di tengah jalan.

b. Kejelasan informasi, dimana komunikasi atau informasi yang diterima oleh para pelaksana kebijakan haruslah jelas dan tidak membingungkan. Kejelasan informasi kebijakan tidak selalu menghalangi implementasi kebijakan, dimana pada tataran tertentu para pelaksana membutuhkan fleksibilitas dalam melaksanakan kebijakan, tetapi pada tataran yang lain maka hal tersebut justru akan menyelewengkan tujuan yang hendak dicapai oleh kebijakan yang telah ditetapkan.

c. Konsistensi informasi yang disampaikan, yaitu perintah ataupun informasi yang diberikan dalam pelaksanaan suatu komunikasi haruslah jelas dan konsisten untuk dapat diterapkan dan dijalankan. 
Ahmad Khoirul Syani, Shohibul Mufid, dan Mufarrihul Hazin : Komunikasi dalam Implementasi Kebijakan Pendidikan Wajib Belajar 9 Tahun Di Kecamatan Ngadiluwih

Apabila perintah yang diberikan seringkali berubah-ubah, maka dapat menimbulkan kebingungan bagi pelaksana di lapangan.

Hasil penelitian menunjukkan $100 \%$ anak di Ngadiluwih yang tamat SD melanjutkan ke SMP/MTS/sederajat. Hal ini menunjukkan bahwa 3 indikator yang mengukur keberhasilan aspek komunikasi dalam implementasi kebijakan telah dicapai dengan sangat baik. Mulai dari aspek transmisi, yaitu sosialisasi yang baik yang dapat dilaksanakan oleh implementator kebijakan. Selanjutnya adalah kontinyunitas atau keberlanjutan penindakan, yaitu pemerintah daerah khususnya wilayah ngadiluwih memfasilitasi anak-anak untuk menyelesaikan pendidikan dasar 9 tahun tanpa takut dengan pembiayaan, karena sudah di gratiskan.Aspek yang terkahir adalah kejelasan informasi, yaitu kebijakan harus jelas dan tidak membingungkan implementator kebijakan.

Menurut Asnawi, Kepala UPTD kecamatan Ngadiluwih, menjelaskan bahwa "angka $100 \%$ dari siswa-siswi ngadiluwih yang melanjutkan ke jenjang selanjutnya (SMP/MTs/sederajat) itu bisa di capai semata-mata karena kesadaran masyarakat sekitar yang sangat tinggi tentang pentingnya sebuah pendidikan. Beliau juga menjelaskan 3 unsur yang mempengaruhi berhasil tidaknya kebijakan dalam penerapan sebuah kebijakan adalah pemerintah, keluarga dan masyarakat.3 unsur tersebut harus berjalan seiring, karena sebaik apapun kebijakan yang dikeluarkan pemerintah, apabila masyarakat tidak antusias dan tidak menjadi implementator kebijakan yang baik, maka suatu kebijakan penerapannya di anggap kurang baik.

Dalam aspek komunikasi beliau juaga menambahkan, bahkan di sini selama menjabat sebagai kepala UPTD Ngadiluwih tidak ditemukan kendala-kendala yang berarti dalam aspek komunikasi dalam implementasi 
kebijakan ini. Bahkan angka putus sekolah pada bangku SMP di daerah ini tidak sampai $1 \%$ atau tepatnya hanya sekitar $0,6 \%$ dari 1142 siswa SD yang melanjutkan ke jenjang selanjutnya.

\section{KESIMPULAN}

Kesimpulan dari penelitian ini menunjukkan bahwa lebijakan 9 tahun wajib belajar telah terlaksana dengan baik. Hal ini dikarenakan: 1) sosialisasi dalam implementasi kebijakan ada 4 aspek yang sangat mempengaruhi keberhasilan dalam sebuah implementasi kebijakan, yang salah satunya adalah aspek komunikasi, dalam komunikasi terdapat 3 indikator yaitu transmisi, kontinyunitas dan kejelasan kebijakan. Dalam penelitian ini, komunikasi dalam implementasi kebijakan pendidikan wajib belajar 9 tahun di kecamatan Ngadiluwih sudah berjalan dengan sangat baik bahkan mendekati sempurna. Hal itu diperkuat dengan data 100\% siswa-siswi yang lulus SD melanjutkan ke SMP/MTs/sederajat, dengan angka putus sekolah tidak sampai mencapai $1 \%$.

\section{DAFTAR PUSTAKA}

Edwards III, George C. Implementing Public Policy. Washington D.C. Congressional Quarterly Inc. 1980.

MufarrihulHazin, "Implementation of Character Education Policy in Colleges".Jurnal Kebijakan dan Pendidikan.2016.

Sugiyono.Metode Penelitian Kuantitatif, Kualitatif. Bandung: Alfabeta. 2017. 
Ahmad Khoirul Syani, Shohibul Mufid, dan Mufarrihul Hazin : Komunikasi dalam Implementasi Kebijakan Pendidikan Wajib Belajar 9 Tahun Di Kecamatan Ngadiluwih

Suharsimi Arikunto. 2006. Prosedur Penelitian Suatu Pendekatan Praktik. Jakarta: Rineka Cipta.

Tilaar, H.A.R. dan Riant Nugroho, Kebijakan Pendidikan, Pengantar Untuk Memaahami Kebijakan Pendidikan Dan Kebijakan Pendidikan Sebagai Kebijakan Publik.Yogyakarta: Pustaka Pelajar. 2012.

WahyuBarmawi. "Analisis Implementasi Kebijakan Wajib Belajar 9 Tahun dalam Meningkatkan Mutu Pendidikan di Kota Ternate".Jurnal Ilmu Pemerintahan \& Kebijakan Publik.Vol. 3 No. 1 Februari 2016.

PP no 47 tahun 2008. 